Article

\title{
Green catalytic oxidation of benzyl alcohol over Pt/ZnO in base-free aqueous medium at room temperature
}

\author{
Juanjuan Liu a , Shihui Zou b,*, Jiachao Wu a, Hisayoshi Kobayashi c,\#, Hongting Zhao a , Jie Fan b,\$ \\ a College of Materials \& Environmental Engineering, Hangzhou Dianzi University, Hangzhou 310036, Zhejiang, China \\ b Key Lab of Applied Chemistry of Zhejiang Province, Department of Chemistry, Zhejiang University, Hangzhou 310027, Zhejiang, China \\ c Department of Chemistry and Materials Technology, Kyoto Institute of Technology, Matsugasaki, Sakyo-ku, Kyoto 606-8585, Japan
}

\section{A R T I C L E I N F}

\section{Article history:}

Received 27 December 2017

Accepted 3 January 2018

Published 5 June 2018

\section{Keywords:}

$\mathrm{Pt} / \mathrm{ZnO}$

Selective oxidation

Benzyl alcohol

C-H activation

Aqueous medium

Room temperature

\begin{abstract}
A B S T R A C T
The selective oxidation of alcohol using molecular oxygen as an oxidant and water as a green solvent is of great interest in green chemistry. In this work, we present a systematic study of a Pt/ZnO catalyst for the selective oxidation of benzyl alcohol at room temperature under base-free aqueous conditions. Experimental observations and density functional theory calculations suggest that $\mathrm{ZnO}$ as a support can facilitate the adsorption of benzyl alcohol, which subsequently reacts with the activated oxygen species on the Pt catalyst, producing benzaldehyde. The resulting solid achieves a high conversion ( $94.1 \pm 5.1 \%$ in $10 \mathrm{~h}$ ) of benzyl alcohol and nearly $100 \%$ selectivity to benzaldehyde with ambient air as the oxidant. In addition, by introducing a small amount of Bi (1.78 wt\%) into Pt/ZnO, we can further enhance the activity by $350 \%$.
\end{abstract}

(C) 2018, Dalian Institute of Chemical Physics, Chinese Academy of Sciences. Published by Elsevier B.V. All rights reserved.

\section{Introduction}

The catalytic oxidation of alcohol into aldehydes/ketones is of great importance at both the laboratorial and industrial levels, and is one of the most challenging reactions to conduct in green chemistry [1-6]. To achieve environmental and economic acceptability, significant effort has been devoted to the development of advanced catalysts that can use molecular oxygen as an environmentally friendly oxidant [7]. Traditionally, most studies are conducted in organic solvents or under solvent-free conditions, and the resulting mixtures of the organic substrates, products, solvents, and molecular oxygen can be quite danger- ous [8]. Anhydrous conditions, in contrast, are impractical because water is formed during the reaction [9]. Considering that water is a safe, cheap, and environmental friendly solvent, it is highly desirable to develop efficient catalysts under aqueous conditions. Owing to their ability to activate molecular oxygen and the $\mathrm{C}-\mathrm{H}$ bonds of alcohol, Pt nanoparticles are generally acknowledged as effective catalysts for alcohol oxidation reactions [10-12]. In addition, the high performance of such nanoparticles in water, the most promising green solvent, is also appealing $[13,14]$. However, the reaction must be carried out at relatively high temperatures $\left(>80^{\circ} \mathrm{C}\right)[15,16]$ and oxygen pressures $(>0.1 \mathrm{MPa})[17]$ with the addition of bases $(\mathrm{NaOH}$,

\footnotetext{
* Corresponding author. Tel/Fax: +86-571-87952338; E-mail: xueshan199@163.com

\# Corresponding author. E-mail: hisabbit@yahoo.co.jp

\$ Corresponding author. Tel/Fax: +86-571-87952338; E-mail: jfan@zju.edu.cn

This work was supported by the National Natural Science Foundation of China (21703050, 21271153, 21373181), China Postdoctoral Science Foundation (512200-X91701), and Special Research Foundation of Young Teachers in Hangzhou Dianzi University (ZX150204307002/032). DOI: 10.1016/S1872-2067(18)63022-0 | http://www.sciencedirect.com/science/journal/18722067 | Chin. J. Catal., Vol. 39, No. 6, June 2018
} 
$\mathrm{K}_{2} \mathrm{CO}_{3}$, etc.) [18], inevitably leading to severe problems such as undesirable side reactions, catalyst corrosion, and the requirement of an extra waste base treatment. From the viewpoint of green chemistry, it is of great interest to functionalize Pt catalysts for the selective oxidation of alcohol in the presence of atmospheric oxygen and the absence of a base at ambient pressure and room temperature.

Previous studies have mainly focused on the exploration of efficient structural or electronic modifiers for Pt nanoparticles [19-22]. Metal promoters, particularly $\mathrm{Bi}$ and $\mathrm{Pb}$, have been demonstrated to drastically enhance the activity of Pt catalysts for alcohol oxidation by preventing an over-oxidation and poisoning of the Pt [23,24]. In contrast, relatively few studies have been devoted to the rational design of Pt catalysts based on a fundamental understanding of the elementary steps. Taking into account the fact that the adsorption and activation of molecular oxygen and alcohol are key steps in alcohol oxidation, it appears to us that the catalytic performance is able to be enhanced by introducing active components that facilitate the above important steps. Our previous study demonstrated that a partially reduced $\mathrm{Bi}_{2} \mathrm{O}_{3-x}$ support can improve the activation of oxygen, which consequently enhances the catalytic performance of Pt nanoparticles for the selective oxidation of benzyl alcohol in a base-free aqueous medium with atmospheric oxygen as an oxidant [25]. To further prove this concept, effort should also be devoted to the fabrication and understanding of novel catalytic systems that can improve the activities of $\mathrm{Pt}$ nanoparticles by accelerating the alcohol adsorption and $\mathrm{C}-\mathrm{H}$ activation.

Herein, we report a newly developed Pt/ZnO catalyst that enables efficient benzyl alcohol oxidation at room temperature under base-free aqueous conditions. Systematic experiments and density functional theory (DFT) calculations suggest that there is a synergistic effect between Pt and ZnO. Specifically, $\mathrm{ZnO}$ as a support can facilitate the adsorption of benzyl alcohol, which subsequently reacts with the activated oxygen species in a Pt catalyst to produce benzaldehyde. In addition, such activity showed an improvement of $350 \%$ with a small addition of Bi to the $\mathrm{Pt} / \mathrm{ZnO}$ catalyst without any decrease in the selectivity.

\section{Experimental}

\subsection{Materials}

The materials used are as follows: deionized (DI) water, hexachloroplatinic acid (Sigma-Aldrich), sodium borohydride (Sigma-Aldrich), zinc oxide (Sinopharm Chemicals and Sigma-Aldrich), bismuth nitrate pentahydrate (Sinopharm Chemicals), and benzyl alcohol (Sinopharm Chemicals). All chemicals were used as received.

\subsection{Preparation}

Briefly, $1 \mathrm{~g}$ of $\mathrm{ZnO}$ powder was dispersed into $10 \mathrm{~mL}$ of DI water, followed by the addition of $2.66 \mathrm{~mL}$ of $\mathrm{H}_{2} \mathrm{PtCl}_{6} \cdot 6 \mathrm{H}_{2} \mathrm{O}$ (19.2 $\mathrm{mmol} \mathrm{L}^{-1}$ ) into the above mixture under vigorous stirring at room temperature. Next, $2 \mathrm{~mL}$ of cold DI water containing 8 mg of $\mathrm{NaBH}_{4}$ was then slowly dropped into the above mixture. The color of the solution changed from light yellow to grey very quickly, indicating the successful formation of Pt nanoparticles. The mixture was further stirred for $2 \mathrm{~h}$ before being centrifuged, and then washed three times using ethanol and DI water. The solid obtained was dried at $65{ }^{\circ} \mathrm{C}$ overnight in a vacuum oven, and labeled as a Pt/ZnO catalyst. The actual content of the Pt was determined to be $0.80 \mathrm{wt} \%$ using ICP-MS.

One gram of $\mathrm{ZnO}$ powder, $2.66 \mathrm{~mL}$ of $\mathrm{H}_{2} \mathrm{PtCl}_{6} \cdot 6 \mathrm{H}_{2} \mathrm{O}(19.2 \mathrm{~m}$ $\mathrm{mmol} \mathrm{L}-1)$, and $48.5 \mathrm{mg}$ of $\mathrm{Bi}\left(\mathrm{NO}_{3}\right)_{3} \cdot 5 \mathrm{H}_{2} \mathrm{O}$ were mixed in $10 \mathrm{~mL}$ of DI water under vigorous stirring at room temperature. Then, $2 \mathrm{~mL}$ of cold DI water containing $8 \mathrm{mg}$ of $\mathrm{NaBH}_{4}$ was dropped into the above mixture. After stirring for $2 \mathrm{~h}$, it was centrifuged, washed using ethanol and DI water three times, and then dried at $65{ }^{\circ} \mathrm{C}$ overnight in a vacuum oven. The as-synthesized solid was labeled as a Pt/Bi-ZnO catalyst. The actual contents of the $\mathrm{Pt}$ and the Bi were determined to be $0.80 \mathrm{wt} \%$ and $1.78 \mathrm{wt} \%$ using ICP-MS, respectively.

\subsection{Characterizations}

Wide-angle X-ray diffraction (WAXRD) patterns were recorded on a Rigaku Ultimate IV using $\mathrm{Cu} K_{\alpha}$ radiation. Transmission electron microscopy (TEM) measurements were performed on a JEOL JEM-1230 operated at $80 \mathrm{kV}$. High-angle annular dark-field scanning transmission electron microscopy (HAADF-STEM) images were obtained on a TECNAI G2 F20 operated at $200 \mathrm{kV}$. High-resolution X-ray photoelectron spectroscopy (XPS) measurements were carried out using a VG Scientific ESCALAB Mark II spectrometer equipped with two ultra-high vacuum (UHV) chambers. Nitrogen sorption data were obtained on a Micromeritics ASAP 2020 adsorption analyzer.

\subsection{Catalytic reaction}

In brief, $0.1 \mathrm{~g}$ of a catalyst, $0.2 \mathrm{mmol}$ of benzyl alcohol, and $10.0 \mathrm{~mL}$ of $\mathrm{H}_{2} \mathrm{O}$ were vigorously stirred together in a flask in the open air at room temperature $\left(26^{\circ} \mathrm{C}\right)$ in the dark. After several hours, $0.2 \mathrm{~mL}$ of the reactant was taken out with a plastic pipette, diluted with ethanol, and then analyzed using gas chromatography. Octane was utilized as the internal standard to quantify the reaction products. Because no byproducts such as benzoic acid or $\mathrm{CO}_{2}$ were detected, the carbon balance = (moles of unconverted BA + moles of benzaldehyde)/moles of the total BA. The carbon balance was $>99 \%$. For the Arrhenius plots, the catalytic reactions were conducted under identical reaction conditions except for the reaction temperature $(35,45$, 55 , and $65^{\circ} \mathrm{C}$ ). In $\mathrm{O}_{2}$ partial pressure experiments, $\mathrm{N}_{2}$ was employed as the balance gas. The partial pressure of $\mathrm{O}_{2}$ was tuned by charging different amounts of $\mathrm{N}_{2}$ and $\mathrm{O}_{2}$ into the reaction flask using a mass flow controller. The total pressure for $\mathrm{N}_{2}$ and $\mathrm{O}_{2}$ was held at 1 bar.

The recycling tests were carried out as follows. After a catalytic reaction, the solid was separated from the mixture through centrifugation, followed by washing with DI water three times. The solid obtained was dried in an oven at $65{ }^{\circ} \mathrm{C}$ 
overnight before being used for the next cycle.

\subsection{DFT calculations}

DFT calculations were carried out using a plane-wave based program, Castep [26,27]. The Perdew-Burke-Ernzerhof (PBE) function [28] was used along with the ultrasoft-core potentials [29]. The cutoff energies were set to $300 \mathrm{eV}$ for a geometry optimization, and $340 \mathrm{eV}$ for an energy re-evaluation. The electron configurations of the atoms were $\mathrm{H} 1 s^{1}, \mathrm{C} 2 s^{2} 2 p^{2}, 02 s^{2} 2 p^{4}$, $\mathrm{Zn} 3 d^{104} s^{2}$, and $\mathrm{Pt} 5 d^{9} 6 s^{1}$. A ( $\left.\mathrm{ZnO}\right)_{48} \mathrm{Pt}_{10}$ unit cell was employed as a model to interpret the $\mathrm{Pt} / \mathrm{ZnO}$ interface, where the fcc (111) oriented $\mathrm{Pt}_{10}$ cluster is supported by a wurtzite (2110) oriented three-layer $\mathrm{ZnO}$ slab. The lattice constants of the unit cell are $b=12.9971 \AA, c=10.4109 \AA$, and $\alpha=\beta=\gamma=90^{\circ}$. The direction of the $a$-axis includes the vacuum region, and is set to $a=40 \AA$. The lower two layers of the $\mathrm{ZnO}$ slabs were fixed to the crystalline structure, and the top layer, $\mathrm{Pt}_{10}$ cluster, and ad-species were optimized.

\section{Results and discussion}

The microstructures of the Pt/ZnO catalysts were revealed using TEM and HADDF-STEM images. Clearly, the morphology and particle size of the $\mathrm{ZnO}$ (Fig. 1(b)) are almost the same as those of pure ZnO (Fig. 1(a)), suggesting that the microstructure of $\mathrm{ZnO}$ does not change during the loading of $\mathrm{Pt}$. As shown in Fig. 1(c), the Pt particles are well dispersed in the $\mathrm{ZnO}$ framework with a narrow size distribution of $3.2 \pm 0.3 \mathrm{~nm}$. The lattice distance of the individual Pt particle in Fig. 1(d) is ca. $0.23 \mathrm{~nm}$, corresponding well with the lattice fringe spacing of the (111) plane in fcc Pt $(0.228 \mathrm{~nm}$, JCPDS 65-2868) [30]. WAXRD patterns (Fig. 2(a)), however, show no obvious diffraction peaks of Pt for either fresh or spent Pt/ZnO catalysts, presumably owing to the low loading amount, small crystalline size, and good dispersion of Pt on the $\mathrm{ZnO}$ support [31]. In all cases, the well-resolved diffraction peaks can be readily assigned to the ZnO crystalline phase (PDF 36-1451) [32].

XPS measurements were conducted to investigate the chemical states of the Pt and $\mathrm{Zn}$ elements. As depicted in Fig. 2(b), both fresh and spent $\mathrm{Pt} / \mathrm{ZnO}$ catalysts share the same $\mathrm{Zn}$ $2 p$ peaks with pure $\mathrm{ZnO}$, where $\mathrm{Zn} 2 p_{3 / 2}$ and $\mathrm{Zn} 2 p_{5 / 2}$ are located at 1021.8 and $1044.9 \mathrm{eV}$, respectively, indicating that the
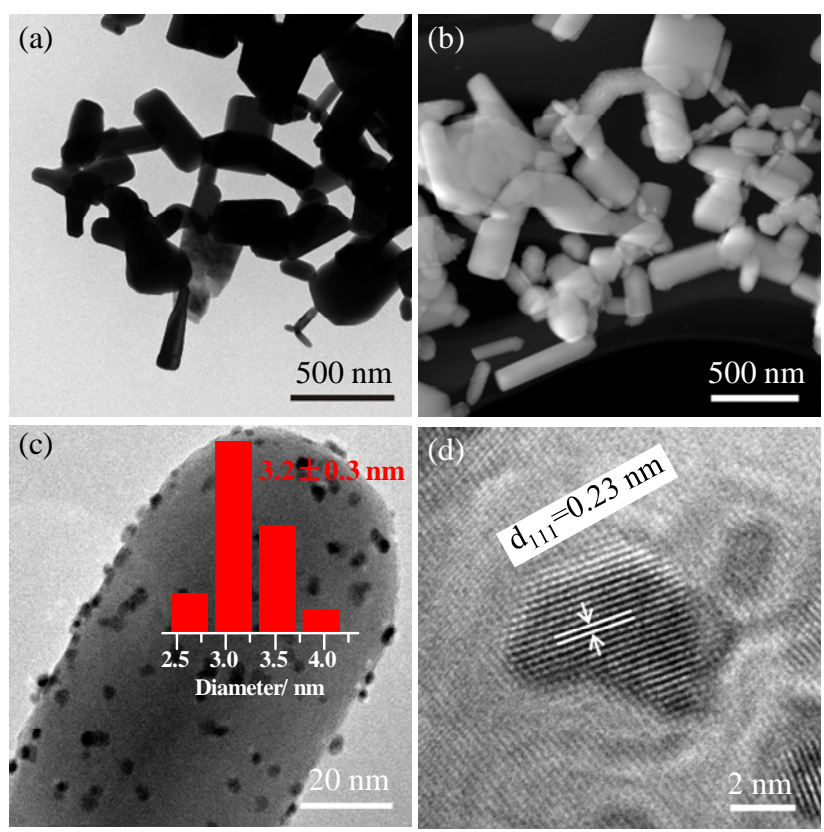

Fig. 1. (a) TEM image of commercial ZnO; HADDF-STEM (b), TEM (c) images of $\mathrm{Pt} / \mathrm{ZnO}$ (size distribution of Pt particles shown in the inset); (d) HRTEM image of supported individual Pt particles on $\mathrm{Pt} / \mathrm{ZnO}$.

presence of $\mathrm{Pt}$ and the catalytic process do not influence the surface electron state of $\mathrm{Zn}^{2+}$ [33]. In contrast, two Gaussian doublets of the Pt peaks in the fresh/spent Pt/ZnO samples are clearly observed in Fig. 2(c), which can be ascribed to the $\mathrm{Pt}^{0}$ (70.2/73.4 eV) [34] and $\mathrm{Pt}^{2+}(71.6 / 75.2 \mathrm{eV})$ species [35], respectively. The latter is likely due to the surface layer formation of Pt- $\mathrm{O}_{\text {ad }}$ bonds during the transfer of samples in air to the XPS chamber, as has been extensively studied in Ref. [36-38]. Notably, the $\mathrm{Pt}^{0} / \mathrm{Pt}^{2+}$ ratios calculated by the peak areas are around 80.8/19.2 for both fresh and spent Pt/ZnO catalysts (fresh, 80.8/19.2; spent, 80.9/19.1), demonstrating the $\mathrm{Pt}^{0}$ species as the dominant form in the $\mathrm{Pt} / \mathrm{ZnO}$ samples. In general, the $\mathrm{Pt}^{0}$ species are accepted as the active sites for oxidative dehydrogenation reactions [11]. It is therefore expected that Pt/ZnO will exhibit an excellent catalytic performance in the selective oxidation of alcohol, as extensively discussed below.

The selective oxidation of benzyl alcohol (BA) into benzaldehyde (BAD) over Pt-based catalysts was carried out in an aqueous medium without any base additives at room temper-
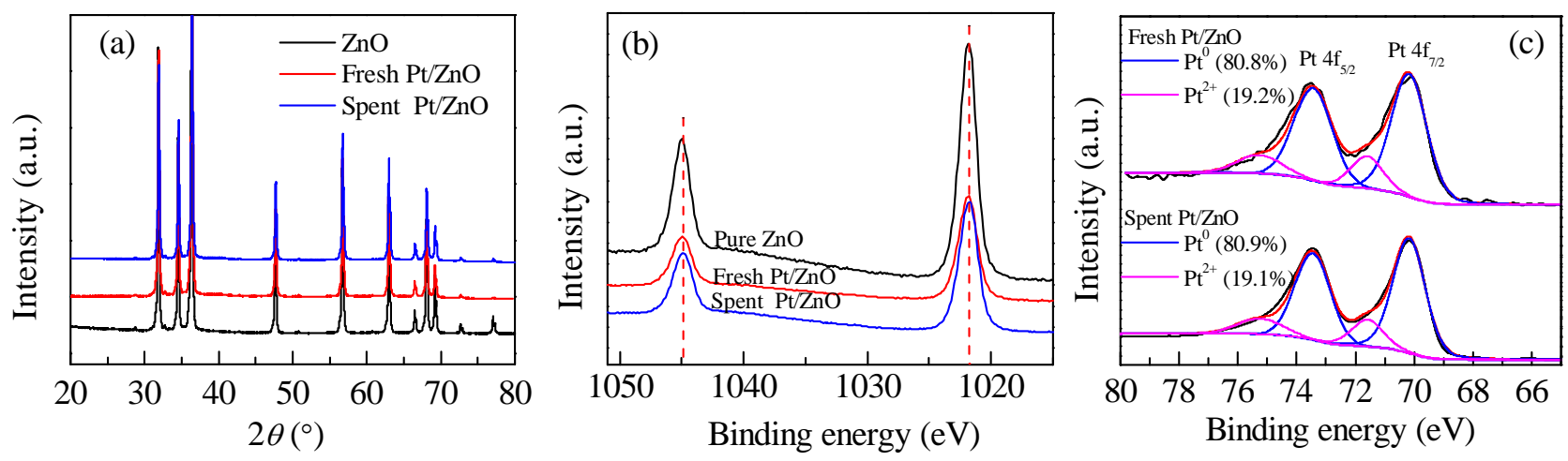

Fig. 2. (a) WAXRD patterns of $\mathrm{ZnO}$, and fresh and spent Pt/ZnO samples; Zn $2 p$ (b) and Pt $4 f$ (c) XPS spectra in fresh and spent Pt/ZnO samples. 


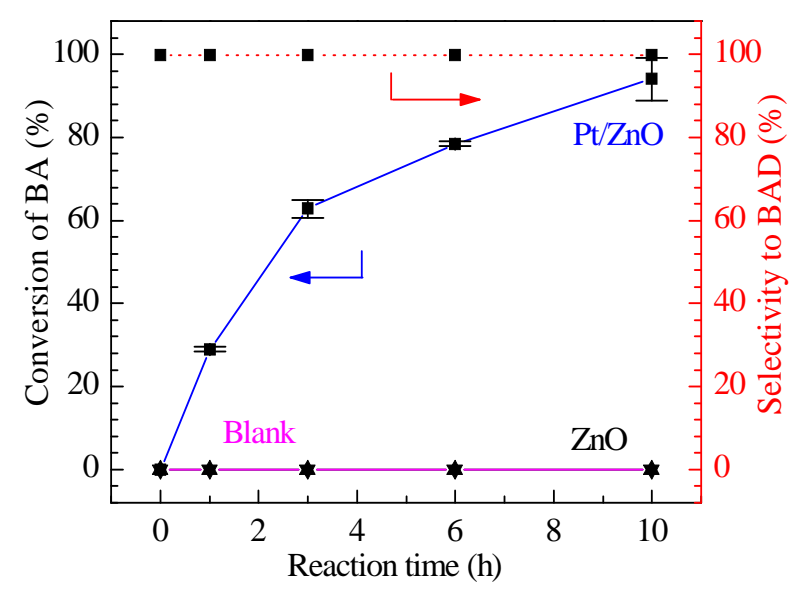

Fig. 3. Time course of alcohol oxidation on $\mathrm{Pt} / \mathrm{ZnO}$ under aqueous conditions at room temperature. Reaction conditions: $0.1 \mathrm{~g}$ catalyst and 0.2 mmol benzyl alcohol in $10 \mathrm{~mL} \mathrm{H}_{2} \mathrm{O}$ at $26^{\circ} \mathrm{C}$.

ature. Ambient air is used as a green oxidant. Fig. 3 shows the time course of $\mathrm{BA}$ oxidation using a $\mathrm{Pt} / \mathrm{ZnO}$ catalyst at room temperature. Control experiments demonstrate that neither the blank reaction without a catalyst nor the pure $\mathrm{ZnO}$ can produce a detectable conversion. Meanwhile, the conversion of benzyl alcohol using a Pt/ZnO catalyst can be as high as $94.1 \pm$ $5.1 \%$ within $10 \mathrm{~h}$, indicating that the presence of both Pt and $\mathrm{ZnO}$ is critical for alcohol oxidation. No benzoic acid or other side products were detected, implying that the selectivity required to produce $\mathrm{BAD}$ is nearly $100 \%$. Meanwhile, we also prepared $0.81 \mathrm{wt} \% \mathrm{Pt} / \mathrm{Al}_{2} \mathrm{O}_{3}, 0.81 \mathrm{wt} \% \mathrm{Pt} / \mathrm{TiO}_{2}$, and $0.83 \mathrm{wt} \%$ $\mathrm{Pt} / \mathrm{MgO}$ using the same method as for $0.80 \mathrm{wt} \% \mathrm{Pt} / \mathrm{ZnO}$. TEM images suggest they achieve similar sizes for the PtNPs. The physicochemical properties and catalytic activities are summarized in Table 1. Interestingly, the TOF $\left(\mathrm{h}^{-1}\right)$ for BA oxidation within $10 \mathrm{~h}$ is $6.2\left(\mathrm{Al}_{2} \mathrm{O}_{3}\right), 1.4(\mathrm{MgO}), 9.5\left(\mathrm{TiO}_{2}\right), 13.0(\mathrm{ZnO})$, and $0\left(\mathrm{SiO}_{2}\right)$, respectively, clearly indicating that the activity depends on the oxide support. Among the various catalysts, $\mathrm{Pt} / \mathrm{ZnO}$ shows the optimal activity. The TOF of Pt/ZnO is 3.5 times the reported $1.08 \mathrm{wt} \% \mathrm{Pt} / \mathrm{Ca}(\mathrm{Mg})$-ZSM catalysts under similar experimental conditions $\left(13.0 \mathrm{~h}^{-1}\right.$ versus $3.69 \mathrm{~h}^{-1}$ per surface Pt atom) [39], which is likely due to the synergistic effect between the $\mathrm{Pt}$ and $\mathrm{ZnO}$ support.

Monitoring the reaction profiles and analyzing the reaction kinetics are very useful for illuminating the mechanistic details. Fig. 4(a) shows Arrhenius plots of Pt/ZnO. The apparent activation energy of BA oxidation over $\mathrm{Pt} / \mathrm{ZnO}$ is as low as $23.7 \mathrm{~kJ}$ mol-1 $^{-1}$, similar to the value reported in Ref. [39]. The similar apparent activation energy and different TOF values suggest different pre-exponential factors for Pt/ZnO and Pt/Ca-ZSM-5. The higher TOF value for $\mathrm{Pt} / \mathrm{ZnO}$ is likely due to the facilitated adsorption of reactants induced by the synergistic effect between the Pt and ZnO. Additionally, we also carried out kinetic studies to study the effect of the partial pressure of $\mathrm{O}_{2}$ on the conversion of benzyl alcohol. As shown in Fig. 4(b), with the partial pressure of $\mathrm{O}_{2}$ increasing from 0 to 0.10 , the conversion of BA increases from 0 to $45.7 \%$, indicating that the reaction is limited by the adsorption and activation of oxygen. Further increasing the $\mathrm{O}_{2}$ partial pressure from 0.10 to 0.21 , the conversion of BA remains steady (ca. 46\%). The independence of the oxygen pressure on the reaction rate of $\mathrm{Pt} / \mathrm{ZnO}$ implies that the $\mathrm{O}_{2}$ adsorption and activation are no longer rate-controlled within this $\mathrm{O}_{2}$ partial pressure range (0.10-0.21) [40]. Notably, our catalytic tests were conducted in ambient air, in which the $\mathrm{O}_{2}$ ratio is ca. 0.21 , corresponding to the point marked in light green in Fig. 4(b), suggesting that the activity of Pt/ZnO is most likely restricted by the alcohol adsorption and activation in the open air rather than the $\mathrm{O}_{2}$ adsorption and activation [41].

To test the proposed hypothesis, we explored the kinetic isotope effect (KIE) through the use of benzyl-d7 alcohol $\left(\mathrm{C}_{6} \mathrm{D}_{5} \mathrm{CD}_{2} \mathrm{OH}\right)$ and benzyl alcohol-OD $\left(\mathrm{C}_{6} \mathrm{H}_{5} \mathrm{CH}_{2} \mathrm{OD}\right)$ as substrates in the selective oxidation. As shown in Fig. 4(c), by replacing $\mathrm{C}_{6} \mathrm{H}_{5} \mathrm{CH}_{2} \mathrm{OH}$ with $\mathrm{C}_{6} \mathrm{H}_{5} \mathrm{CH}_{2} \mathrm{OD}$, the conversion remains almost unchanged $\left(28.9 \mathrm{~h}^{-1}\right.$ per surface $\mathrm{Pt}$ atom versus $27.5 \mathrm{~h}^{-1}$ per surface Pt atom). In contrast, the reaction was slowed down by a factor of $6.28\left(28.9 \mathrm{~h}^{-1}\right.$ per surface Pt atom versus $4.6 \mathrm{~h}^{-1}$ per surface Pt atom) once the $\mathrm{C}_{6} \mathrm{H}_{5} \mathrm{CH}_{2} \mathrm{OH}$ was replaced with $\mathrm{C}_{6} \mathrm{D}_{5} \mathrm{CD}_{2} \mathrm{OH}$, clearly demonstrating that the cleavage of $\mathrm{C}-\mathrm{H}$ is a rate-determining step. Moreover, we also tested the catalytic oxidation of substituted benzyl alcohol on Pt/ZnO to further confirm the result. In principle, benzyl alcohol substituted using electron-donating groups has a weak $\mathrm{C}-\mathrm{H}$ bond, which might consequently lead to a high reaction rate. As shown in Fig. 4(d), $100 \%$ conversion of 4-methylbenzyl alcohol and 4-methoxybenzyl alcohol can be achieved within only $5 \mathrm{~h}$, consistent with our hypothesis. On the other hand, when benzyl alcohol molecules were substituted using $-\mathrm{NO}_{2}$ (the electron-withdrawing groups), the conversion of 4-nitrobenzyl alcohol after $5 \mathrm{~h}$ is only $3.3 \%$, which is much lower than that of BA. No correlations were found between the reactivity and octanol-water partition coefficients [42] of aromatic alcohol (4-methylbenzyl alcohol > 4-nitrobenzyl alcohol > 4-methoxybenzyl alcohol $\approx$ benzyl alcohol), indicating that the electronic

Table 1

Physicochemical properties and catalytic activities of various supported Pt catalysts.

\begin{tabular}{|c|c|c|c|c|c|c|}
\hline Catalyst & Pt loading (wt\%) & $d_{\mathrm{Pt}^{\mathrm{a}}}(\mathrm{nm})$ & Pt dispersion ${ }^{b}$ & Surface area $\left(\mathrm{m}^{2} \mathrm{~g}^{-1}\right)$ & Conv. (\%) & $\mathrm{TOF}^{\mathrm{c}}\left(\mathrm{h}^{-1}\right)$ \\
\hline $\mathrm{Pt} / \mathrm{ZnO}$ & 0.80 & $3.2 \pm 0.3$ & 0.35 & 5.0 & 94.1 & 13.0 \\
\hline $\mathrm{Pt} / \mathrm{Al}_{2} \mathrm{O}_{3}$ & 0.81 & $3.4 \pm 0.4$ & 0.33 & 149.9 & 43.0 & 6.2 \\
\hline $\mathrm{Pt} / \mathrm{MgO}$ & 0.83 & $2.5 \pm 0.3$ & 0.45 & 26.4 & 13.3 & 1.4 \\
\hline $\mathrm{Pt} / \mathrm{SiO}_{2}$ & 0.83 & $2.9 \pm 0.3$ & 0.39 & 423.0 & 0 & 0 \\
\hline $\mathrm{Pt} / \mathrm{TiO}_{2}$ & 0.81 & $3.5 \pm 0.5$ & 0.32 & 51.3 & 63.4 & 9.5 \\
\hline
\end{tabular}

a The average particle size of Pt determined using TEM.

${ }^{\mathrm{b}}$ dispersion $=1.13 / d_{\mathrm{Pt}}[11]$.

c Defined as the amount of benzyl alcohol reacted per hour per surface Pt site. 

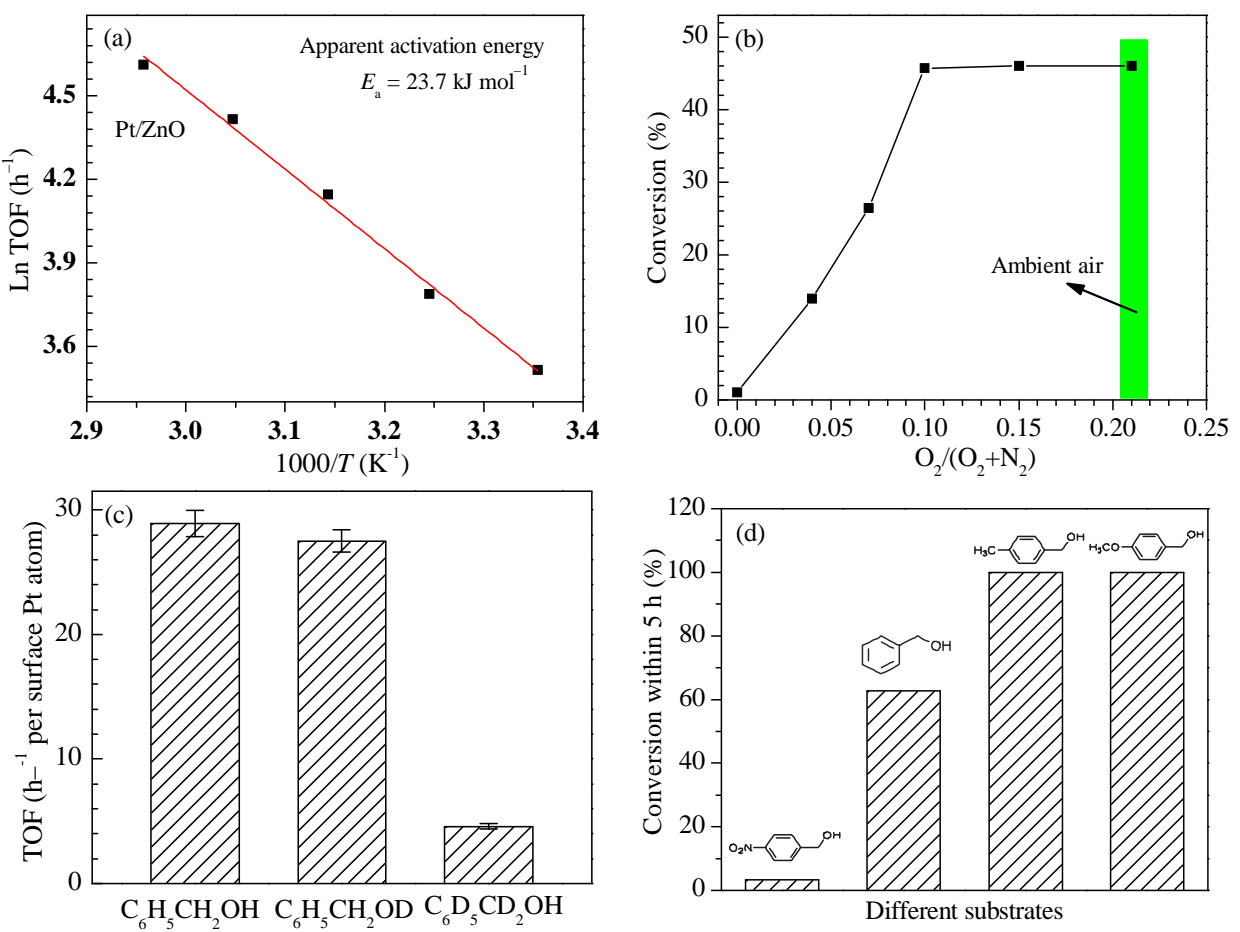

Fig. 4. (a) Arrhenius plots for alcohol oxidation in the open air on Pt/ZnO catalyst; (b) Kinetic study of the $\mathrm{O}_{2}$ partial pressure on the conversion for a $\mathrm{Pt} / \mathrm{ZnO}$ catalyst at room temperature within $2 \mathrm{~h}$ (the $\mathrm{O}_{2}$ pressure in ambient air is marked in light green); (c) Kinetic isotope effect observed for $\mathrm{Pt} / \mathrm{ZnO}$ at room temperature within $3 \mathrm{~h}$; (d) Conversion of substituted benzyl alcohol on the Pt/ZnO catalyst within $5 \mathrm{~h}$. In all cases, the selectivity is > $99 \%$.

properties of the substituent groups play a more significant role than the relative solubility of the reagents in water [43]. Taking all of these results together, it is clear that the $\mathrm{C}-\mathrm{H}$ activation determines the catalytic oxidation of $\mathrm{BA}$ in $\mathrm{Pt} / \mathrm{ZnO}$ in open air at room temperature.

DFT calculations were conducted to provide molecular level insight into the reaction pathways, as well as to elucidate the nature of the catalytic mechanism. In this case, a $(\mathrm{ZnO})_{48} \mathrm{Pt}_{10}$ unit cell was employed as a model to interpret the $\mathrm{Pt} / \mathrm{ZnO}$ interface. Similar simulations have been extensively reported in the literature as an investigation in the metal-oxide interface $[44,45]$. To calculate a possible reaction pathway, the entire oxidative dehydrogenation processes $2 \mathrm{PhCH}_{2} \mathrm{OH}+\mathrm{O}_{2} \rightarrow$ $2 \mathrm{PhCHO}+2 \mathrm{H}_{2} \mathrm{O}$ are divided into two parts. Each part involves the production of a PhCHO molecule. The former half of BA-to-BAD is shown in Fig. 5. The individual optimized structures for the local minima (LMs) and the transition states (TSs) are described using configuration numbers \#1 to \#10.

The reaction is initiated through the dissociative adsorption of $\mathrm{O}_{2}$ molecules, with the $\mathrm{O}$ species formed being bonded to $\mathrm{Pt}$ atoms (\#1 to \#3). The activation energy of this step is only 20.1 $\mathrm{kJ} \mathrm{mol}-1$, indicating the good capability of $\mathrm{Pt}$ for $\mathrm{O}_{2}$ activation. Meanwhile, $\mathrm{PhCH}_{2} \mathrm{OH}$ is adsorbed into the $\mathrm{ZnO}$ sites, followed by a cleavage of the $\mathrm{O}-\mathrm{H}$ bond on the dissociated $\mathrm{O}$ species (\#4 to \#6) to form $\mathrm{H}-\mathrm{O}(-\mathrm{Pt})$. The activation energy of this step is $44.1 \mathrm{~kJ} \mathrm{~mol}^{-1}\left(\mathrm{PhCH}_{2} \mathrm{OH}+\mathrm{O}(-\mathrm{Pt}) \rightarrow \mathrm{PhCH}_{2} \mathrm{O}+\mathrm{H}-\mathrm{O}(-\mathrm{Pt})\right)$. Subsequently, the $\mathrm{C}-\mathrm{H}$ proton is abstracted using the as-produced $\mathrm{HO}(-\mathrm{Pt})$ according to the reaction $\mathrm{PhCH}_{2} \mathrm{O}+\mathrm{H}-\mathrm{O}(-\mathrm{Pt}) \rightarrow$ $\mathrm{PhCHO}+\mathrm{H}_{2} \mathrm{O}(-\mathrm{Pt}$ ) (\#7 to \#9), accompanied by the formation of a PhCHO molecule and a $\mathrm{H}_{2} \mathrm{O}(-\mathrm{Pt})$ molecule. The former half of the reaction is then completed through the desorption of the $\mathrm{PhCHO}$ and $\mathrm{H}_{2} \mathrm{O}$ molecules (\#10), leaving a single $\mathrm{O}$ atom on the $\mathrm{Pt}$ cluster of the catalyst surface. This $\mathrm{O}$ atom can reproduce the former half reaction with another $\mathrm{PhCH}_{2} \mathrm{OH}$ molecule ac-
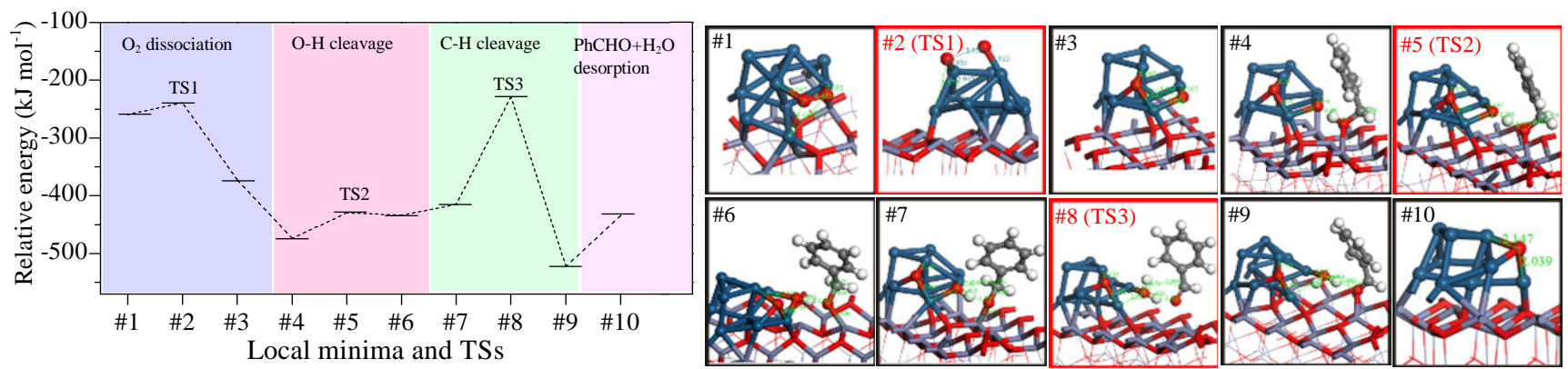

Fig. 5. Energy changes and configurations for LM and TS along the former half of the BA-to-BAD reaction. Pt (dark blue), $\mathrm{O}$ (red), Zn (bluish gray), $\mathrm{H}$ (white), and C (grey). 

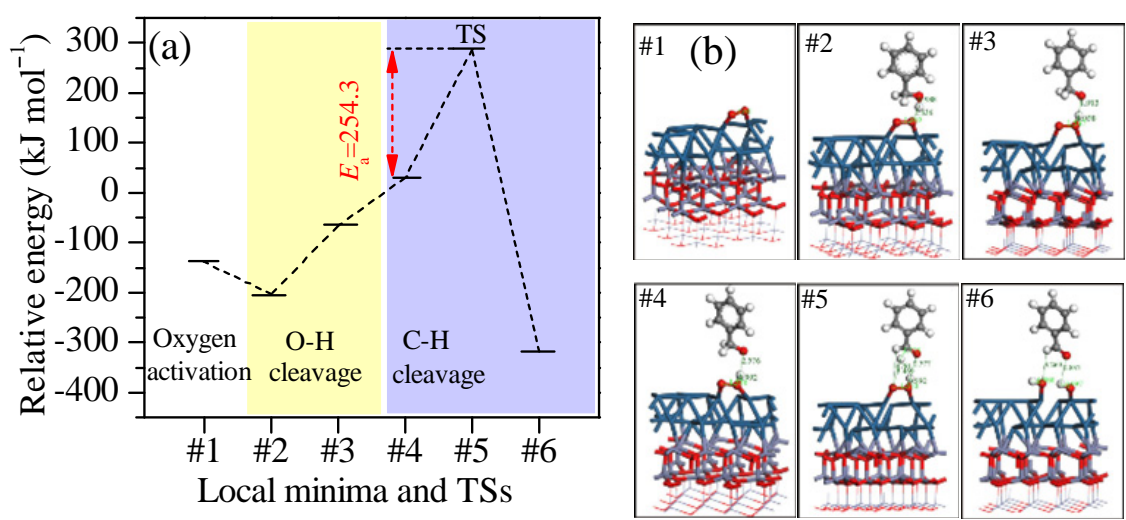

Fig. 6. DFT calculations based on the flat Pt(111)/ZnO(21̄10) surface. (a) Energy profile; (b) Configurations for LMs and transition state TS.

cording to the whole oxidative dehydrogenation processes $\mathrm{PhCH}_{2} \mathrm{OH}+\mathrm{O} \rightarrow \mathrm{PhCHO}+\mathrm{H}_{2} \mathrm{O}$. In addition, $(\mathrm{ZnO})_{48} \mathrm{Pt}_{10}$ cells are regenerated for the next catalytic cycle after the desorption of the second produced benzaldehyde and $\mathrm{H}_{2} \mathrm{O}$ molecules. Notably, the $\mathrm{C}-\mathrm{H}$ proton abstraction through the dissociated $\mathrm{O}$ atom (HO(-Pt)) possesses the highest activation energy (186.5 kJ mol-1), serving as the rate-determining step. Together with kinetic studies, particularly the KIE study in Fig. 4(c), the calculations have led to the belief that the $\mathrm{C}-\mathrm{H}$ activation of the $\mathrm{PhCH}_{2} \mathrm{OH}$ dominates the reaction rate.

In addition, we also conducted DFT calculations on a $\mathrm{Pt}(111) / \mathrm{ZnO}(2110)$ flat surface (Fig. 6). In this case, $\mathrm{ZnO}$ is not directly involved in the catalytic cycle. The $\mathrm{O}-\mathrm{H}$ bond of benzyl alcohol is cleaved through the pre-adsorbed $\mathrm{O}_{2}$, followed by the cleavage of the $\mathrm{C}-\mathrm{H}$ bond to produce benzaldehyde. Interestingly, the corresponding activation energy $E_{\mathrm{a}}$ for a C-H cleavage $\left(E_{\mathrm{a}}=254.3 \mathrm{~kJ} \mathrm{~mol}^{-1}\right)$ is much higher than that of the $(\mathrm{ZnO})_{48} \mathrm{Pt}_{10}$ model $\left(E_{\mathrm{a}}=186.5 \mathrm{~kJ} \mathrm{~mol}^{-1}\right)$, confirming the importance of the $\mathrm{Pt} / \mathrm{ZnO}$ interface. The excellent catalytic performance of $\mathrm{Pt} / \mathrm{ZnO}$ for BA-to-BAD oxidation might result from the synergistic effects of $\mathrm{Pt}$ and $\mathrm{ZnO}$. Specifically, a $\mathrm{ZnO}$ support acts as a site for $\mathrm{PhCH}_{2} \mathrm{OH}$ adsorption, and Pt facilitates the adsorption and activation of $\mathrm{O}_{2}$, which consequently reacts with the adsorbed $\mathrm{PhCH}_{2} \mathrm{OH}$.

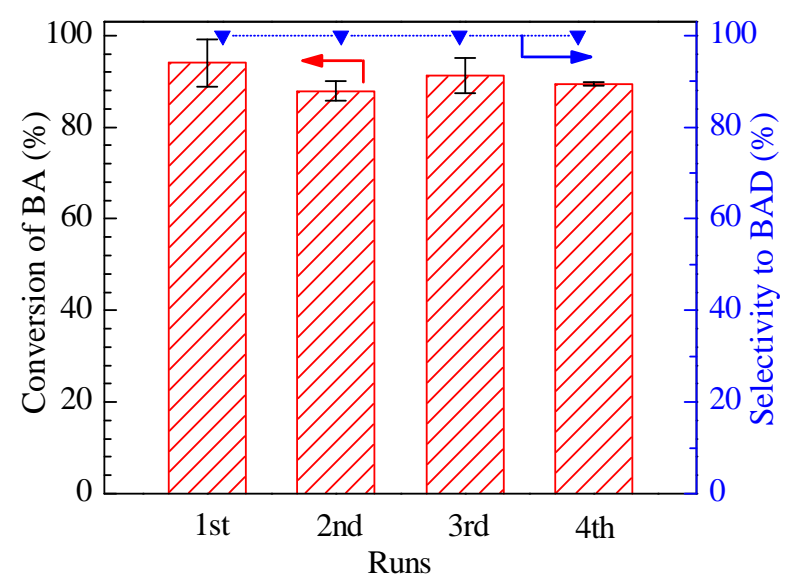

Fig. 7. Recycling tests for alcohol oxidation in the open air on the Pt/ZnO catalyst. Reaction conditions: $0.1 \mathrm{~g}$ catalyst, $0.2 \mathrm{mmol}$ benzyl alcohol in $10 \mathrm{~mL} \mathrm{H} \mathrm{H}_{2}, 26^{\circ} \mathrm{C}, 10 \mathrm{~h}$.
Stability is one of the major concerns for a catalyst in practical applications. In this case, recycling experiments were carried out to assess the stability of a $\mathrm{Pt} / \mathrm{ZnO}$ catalyst for BA-to-BAD oxidation under base-free aqueous conditions at room temperature. As shown in Fig. 7, there is only a slight change in the conversion, and the catalytic selectivity remains steady during the repetition of four continuous cycles. The conversion can reach up to about $95 \%$ within $10 \mathrm{~h}$ during the fourth successive run, affording the selectivity to BAD of higher than $99 \%$. This suggests that a Pt/ZnO catalyst has greater stability than our reported efficient $\mathrm{Pt} / \mathrm{Bi}_{2} \mathrm{O}_{3-x}$ catalyst, which can be quickly deactivated after the first run owing to an over-oxidation of $\mathrm{Bi}_{2} \mathrm{O}_{3-x}$ [25]. The good stability of $\mathrm{Pt} / \mathrm{ZnO}$ is also confirmed based on the HADDF-STEM and TEM images. As shown in Fig. 8, there are no obvious changes in the morphology or particle size of the spent $\mathrm{Pt} / \mathrm{ZnO}$ sample in comparison with the fresh version shown in Fig. 1. Apart from this, the Pt particles with a size distribution of $3.5 \pm 0.3 \mathrm{~nm}$ are isolated and homogeneously distributed on the $\mathrm{ZnO}$ support without severe agglomeration, suggesting a good stability of the Pt/ZnO catalyst. Thus, it can be concluded that a $\mathrm{Pt} / \mathrm{ZnO}$ sample can serve as a stable and efficient catalyst for practical alcohol oxidation at room temperature in an aqueous medium without any base additives.

In addition, p-electron metal, such as bismuth, has been acknowledged as an excellent promoter for a Pt catalyst $[46,47]$. Here, by introducing a small amount of Bi nitrate into a 0.80 wt $\%$ Pt/ZnO catalyst (1.78 wt\% of Bi on the Pt/Bi-ZnO),
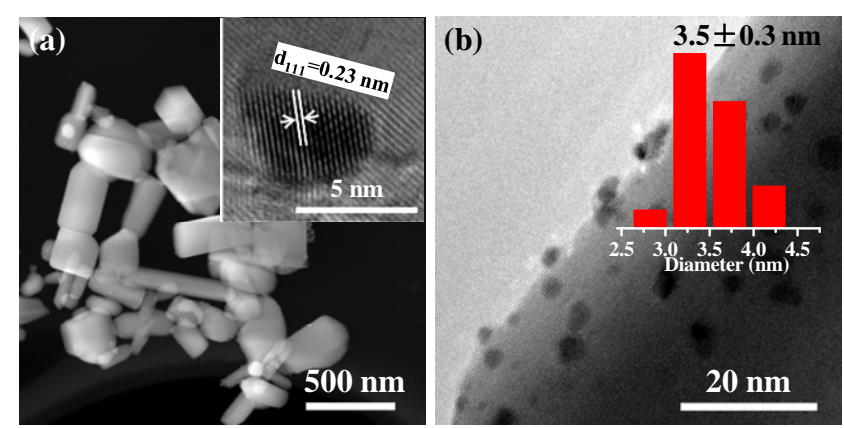

Fig. 8. (a) HADDF-STEM image of spent Pt/ZnO catalyst (HRTEM image of an individual Pt particle inset); (b) TEM image of spent Pt/ZnO catalyst (size distribution of Pt particles shown in the inset). 

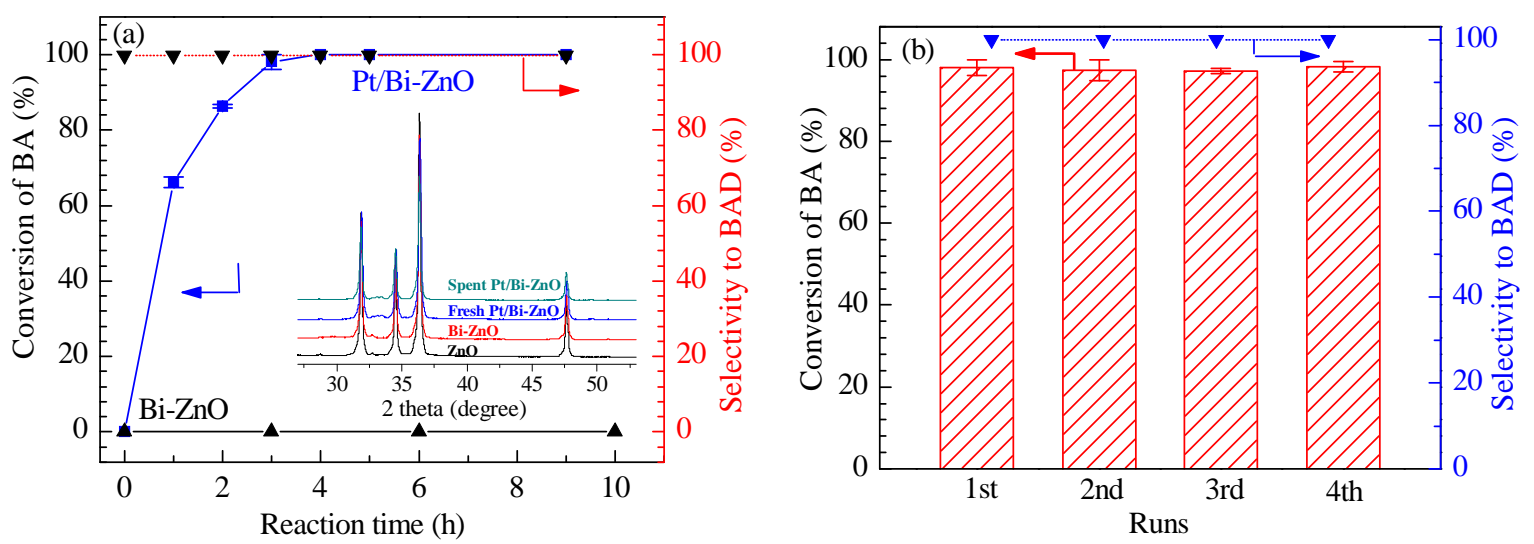

Fig. 9. (a) Time course of alcohol oxidation on $\mathrm{Bi}-\mathrm{ZnO}$ and $\mathrm{Pt} / \mathrm{Bi}-\mathrm{ZnO}$ catalysts (XRD data inset); (b) Recycling tests for alcohol oxidation in the open air on Pt/Bi-ZnO catalyst. Experimental conditions: $0.1 \mathrm{~g}$ catalyst, $0.2 \mathrm{mmol}$ benzyl alcohol in $10 \mathrm{~mL} \mathrm{H}_{2} \mathrm{O}, 26^{\circ} \mathrm{C}, 3 \mathrm{~h}$.

the activity is efficiently improved despite almost no change in the XRD pattern of the Pt/ZnO. As shown in Fig. 9(a), the conversion of alcohol using Pt/ZnO can be greatly enhanced from $94.1 \pm 5.1 \%$ within $10 \mathrm{~h}$ to $98.1 \pm 1.6 \%$ within $3 \mathrm{~h}$ without a decrease in selectivity. The TOF can be improved from 13.0 to $45.2 \mathrm{~h}^{-1}$ per surface Pt atom. To the best of our knowledge, this is the highest TOF ever reported for the selective oxidation of $\mathrm{BA}$ in an aqueous medium under identical reaction conditions. In addition, as shown in Fig. 9(b), no significant decrease in the activity or selectivity was detected even after the fourth cycle, indicating that $\mathrm{Pt} / \mathrm{Bi}-\mathrm{ZnO}$ is more stable than $\mathrm{Pt} / \mathrm{ZnO}$ and $\mathrm{Pt} / \mathrm{Bi}_{2} \mathrm{O}_{3-x}$ during a catalytic reaction [25]. Its excellent performance and green-chemistry compatible process suggests that $\mathrm{Pt} / \mathrm{Bi}-\mathrm{ZnO}$ has significant potential as a catalyst in the selective oxidation of industrial alcohol. A preliminary investigation indicated that a Bi species is present separately on the support in the form of $\mathrm{BiOCl}$, which is distinguished from previous reports [46]. Systematic studies of the promoting role of $\mathrm{Bi}$ on $\mathrm{Pt} / \mathrm{ZnO}$ are ongoing.

\section{Conclusions}

We successfully fabricated a stable and efficient Pt/ZnO catalyst for benzyl alcohol oxidation under base-free aqueous conditions at room temperature. A high activity of $94.1 \pm 5.1 \%$ with nearly $100 \%$ selectivity to benzaldehyde can be obtained with ambient air as an oxidant within $10 \mathrm{~h}$. Kinetic studies indicate that $\mathrm{C}-\mathrm{H}$ activation is a rate-determining step. DFT calculations further confirm that the high activity and selectivity result from the synergistic effect between the Pt and $\mathrm{ZnO}$ support. To be specific, $\mathrm{ZnO}$ provides sites for the adsorption of benzyl alcohol, and Pt facilitates the adsorption and activation of $\mathrm{O}_{2}$, which consequently reacts with adsorbed benzyl alcohol to produce benzaldehyde. Furthermore, introducing a small amount of Bi species into $0.8 \mathrm{wt} \% \mathrm{Pt} / \mathrm{ZnO}$ (1.78 wt\% of Bi on $\mathrm{Pt} / \mathrm{Bi}-\mathrm{ZnO}$ ) can greatly enhance the conversion by $350 \%$ without changing the selectivity. This alcohol oxidation on $\mathrm{Pt} / \mathrm{ZnO}$ is a green chemistry compatible process, which may further facilitate the design of environmentally friendly catalysts for oxidative reactions.

\section{References}

[1] D. I. Enache, J. K. Edwards, P. Landon, B. Solsona-Espriu, A. F. Carley, A. A. Herzing, M. Watanabe, C. J. Kiely, D. W. Knight, G. J. Hutchings, Science, 2006, 311, 362-365.

[2] A. Abad, P. Concepción, A. Corma, H. García, Angew. Chem. Int. Ed., 2005, 44, 4066-4069.

[3] S. Yurdakal, G. Palmisano, V. Loddo, V. Augugliaro, L. Palmisano, J. Am. Chem. Soc., 2008, 130, 1568-1569.

[4] S. Verma, R. B. N. Baig, M. N. Nadagouda, R. S. Varma, ACS Sustain. Chem. Eng., 2016, 4, 1094-1098.

[5] J. W. Che, M. J. Hao, W. Z. Yi, H. Kobayashi, Y. H. Zhou, L. P. Xiao, J. Fan, Chin. J. Catal., 2017, 38, 1870-1879.

[6] W. Hong, X. Q. Yan, R. H. Li, J. Fan, Chin. J. Catal., 2017, 38, 545-553.

[7] S. Higashimoto, N. Kitao, N. Yoshida, T. Sakura, M. Azuma, H. Ohue, Y. Sakata, J. Catal., 2009, 266, 279-285.

[8] W. Hou, N. A. Dehm, R. W. J. Scott, J. Catal., 2008, 253, 22-27.

[9] G. J. ten Brink, I. W. C. E. Arends, R. A. Sheldon, Science, 2000, 287, 1636-1639.

[10] T. Mallat, A. Baiker, Chem. Rev., 2004, 104, 3037-3058.

[11] J. J. Liu, S. H. Zou, L. F. Lu, H. T. Zhao, L. P. Xiao, J. Fan, Catal. Commun., 2017, 99, 6-9.

[12] Y. Z. Chen, Z. U. Wang, H. W. Wang, J. L. Lu, S. H. Yu, H. L. Jiang, J. Am. Chem. Soc., 2017, 139, 2035-2044.

[13] A. Frassoldati, C. Pinel, M. Besson, Catal. Today, 2011, 173, 81-88.

[14] H. Chen, Q. H. Tang, Y. T. Chen, Y. B. Yan, C. M. Zhou, Z. Guo, X. L. Jia, Y. H. Yang, Catal. Sci. Technol., 2013, 3, 328-338.

[15] F. Z. Su, Y. M. Liu, L. C. Wang, Y. Cao, H. Y. He, K. N. Fan, Angew. Chem. Int. Ed., 2008, 47, 334-337.

[16] Y. L. Hong, X. L. Jing, J. L. Huang, D. H. Sun, T. Odoom-Wubah, F. Yang, M. M. Du, Q. B. Li, ACS Sustain. Chem. Eng., 2014, 2, 1752-1759.

[17] N. Dimitratos, A. Villa, D. Wang, F. Porta, D. S. Su, L. Prati, J. Catal., 2006, 244, 113-121.

[18] H. Tsunoyama, H. Sakurai, Y. Negishi, T. Tsukuda, J. Am. Chem. Soc., 2005, 127, 9374-9375.

[19] M. C. Figueiredo, R. M. Arán-Ais, J. M. Feliu, K. Kontturi, T. Kallio, J. Catal., 2014, 312, 78-86.

[20] A. Frassoldati, C. Pinel, M. Besson, Catal. Today, 2013, 203, 133-138.

[21] Y. Kwon, Y. Birdja, I. Spanos, P. Rodriguez, M. T. M. Koper, ACS Catal., 2012, 2, 759-764. 


\title{
Graphical Abstract
}

Chin. J. Catal., 2018, 39: 1081-1089 doi: 10.1016/S1872-2067(18)63022-0

Green catalytic oxidation of benzyl alcohol over $\mathrm{Pt} / \mathrm{ZnO}$ in base-free aqueous medium at room temperature

Juanjuan Liu, Shihui Zou *, Jiachao Wu, Hisayoshi Kobayashi *, Hongting Zhao, Jie Fan *

Hangzhou Dianzi University, China;

Zhejiang University, China;

Kyoto Institute of Technology, Japan

$\mathrm{ZnO}$ as a support can facilitate the adsorption of benzyl alcohol, which subsequently reacts with an activated oxygen species on a Pt catalyst to produce benzaldehyde at room temperature under base-free aqueous conditions.

[22] A. L. Tarasov, L. M. Kustov, A. A. Bogolyubov, A. S. Kiselyov, V. V. Semenov, Appl. Catal. A, 2009, 366, 227-231.

[23] C. Mondelli, J. D. Grunwaldt, D. Ferri, A. Baiker, Phys. Chem. Chem. Phys., 2010, 12, 5307-5316.

[24] T. Mallat, Z. Bodnar, A. Baiker, O. Greis, H. Strubig, A. Reller, J. Catal., 1993, 142, 237-253.

[25] J. J. Liu, S. H. Zou, H. Wang, L. P. Xiao, H. T. Zhao, J. Fan, Catal. Sci. Technol, 2017, 7, 1203-1210.

[26] M. C. Payne, M. P. Teter, D. C. Allan, T. A. Arias, J. D. Joannopoulos, Rev. Mod. Phys., 1992, 64, 1045-1097.

[27] S. H. Zou, J. J. Liu, H. Kobayashi, C. L. Chen, P. S. Qiao, R. H. Li, L. P. Xiao, J. Fan, J. Phys. Chem. C, 2017, 121, 4343-4351.

[28] J. P. Perdew, K. Burke, M. Ernzerhof, Phys. Rev. Lett., 1996, 77, 3865-3868.

[29] D. Vanderbilt, Phys. Rev. B, 1990, 41, 7892-7895.

[30] C. M. Zhou, Z. Guo, Y. H. Dai, X. L. Jia, H. Yu, Y. H. Yang, Appl. Catal. B, 2016, 181, 118-126.

[31] T. Sreethawong, S. Yoshikawa, Int. J. Hydrogen Energy, 2006, 31, 786-796.

[32] J. Zhang, L. D. Sun, C. S. Liao, C. H. Yan, Chem. Commun., 2002, 262-263.

[33] L. Ge, X. Y. Jing, J. Wang, J. Wang, S. Jamil, Q. Liu, F. C. Liu, M. L. Zhang, J. Mater. Chem., 2011, 21, 10750-10754.

[34] M. J. Hossain, H. Tsunoyama, M. Yamauchi, N. Ichikuni, T. Tsukuda, Catal. Today, 2012, 183, 101-107.

[35] Y. Einaga, R. Mikami, T. Akitsu, G. M. Li, Thin Solid Films, 2005,
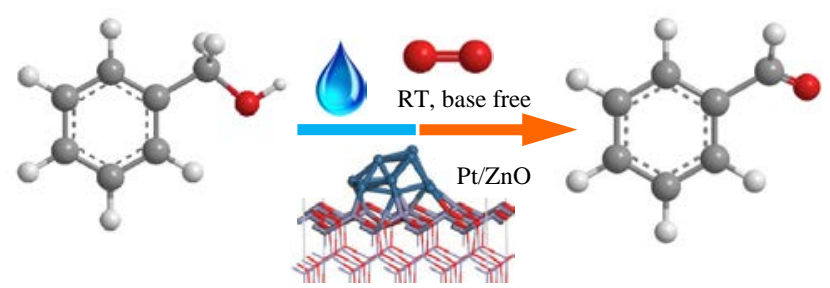

493, 230-236.

[36] G. Neri, C. Milone, S. Galvagno, A. P. J. Pijpers, J. Schwank, Appl. Catal. A, 2002, 227, 105-115.

[37] J. H. Kim, S. M. Choi, S. H. Nam, M. H. Seo, S. H. Choi, W. B. Kim, Appl. Catal. $B, 2008,82,89-102$.

[38] R. F. Nie, D. Liang, L. Shen, J. Gao, P. Chen, Z. Y. Hou, Appl. Catal. B, 2012, 127, 212-220.

[39] Y. J. Hong, X. Q. Yan, X. F. Liao, R. H. Li, S. D. Xu, L. P. Xiao, J. Fan, Chem. Commun., 2014, 50, 9679-9682.

[40] J. H. Xie, B. Huang, K. H. Yin, H. N. Pham, R. R. Unocic, A. K. Datye, R. J. Davis, ACS Catal., 2016, 6, 4206-4217.

[41] Y. H. Dai, X. Q. Yan, Y. Tang, X. N. Liu, L. P. Xiao, J. Fan, ChemCatChem, 2012, 4, 1603-1610.

[42] J. Sangster, Octanol-Water Partition Coefficients: Fundamentals and Physical Chemistry, John Wiley \& Sons, New York, 1997, 1-20.

[43] S. Yurdakal, G. Palmisano, V. Loddo, O. Alagoz, V. Augugliaro, L. Palmisano, Green Chem., 2009, 11, 510-516.

[44] A. Bruix, J. A. Rodriguez, P. J. Ramírez, S. D. Senanayake, J. Evans, J. B. Park, D. Stacchiola, P. Liu, J. Hrbek, F. Illas, J. Am. Chem. Soc., 2012, 134, 8968-8974.

[45] J. A. Rodríguez, J. Evans, J. Graciani, J. B. Park, P. Liu, J. Hrbek, J. F. Sanz, J. Phys. Chem. C, 2009, 113, 7364-7370.

[46] T. Mallat, Z. Bodnar, P. Hug, A. Baiker, J. Catal., 1995, 153, 131-143.

[47] C. M. Zhou, Z. Guo, Y. H. Dai, X. L. Jia, H. Yu, Y. H. Yang, Appl. Catal. B, 2016, 181, 118-126.

\section{$\mathrm{Pt} / \mathrm{ZnO}$ 在室温水相无碱条件下绿色催化苯甲醇选择性氧化}

\author{
刘娟娟 ${ }^{\mathrm{a}}$, 邹世辉 ${ }^{\mathrm{b}, *}$, 吴嘉超 ${ }^{\mathrm{a}}$, Hisayoshi Kobayashi ${ }^{\mathrm{c}, \#}$, 赵红挺 ${ }^{\mathrm{a}}$, 范 杰 ${ }^{\mathrm{b}, \$}$ \\ a杭州电子科技大学材料与环境工程学院, 浙江杭州 310018, 中国

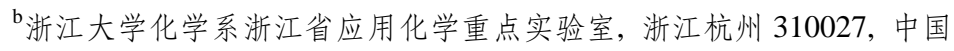 \\ c京都工艺纤维大学, 京都 606-8585, 日本
}

\begin{abstract}
摘要: 醇类化合物选择性氧化是有机合成中一个非常重要的反应, 在精细化工领域具有重要应用. 而以水为绿色溶剂, 分 子氧为绿色氧化剂实现醇类化合物选择性氧化是绿色化学领域的一大挑战. Pt 催化剂由于其优异的活化氧气和 C-H 键的 能力在该反应中得到了广泛应用. 但是, 常规的 Pt 催化剂通常需要在较高温度和较高氧气压力以及加碱的条件下才能发 挥作用, 从而引起了催化剂腐蚀等一系列问题. 从绿色化学角度出发, 进一步优化 Pt 催化剂, 让其能够在室温无碱条件下 以空气为氧化剂选择性氧化醇类合成羰基化合物具有重要的研究价值和应用前景.
\end{abstract}


本文通过化学还原法制备了 $\mathrm{Pt} / \mathrm{ZnO}$ 催化剂, 系统研究了该催化剂在水相无碱条件下选择性氧化苯甲醇生成苯甲醛反 应中的催化性能. $\mathrm{X}$ 射线电子衍射和透射电镜等结果表明, Pt 颗粒较小 $(3.2 \pm 0.3 \mathrm{~nm})$, 均匀分散在 $\mathrm{ZnO}$ 载体上; X 射线光 电子能谱表明 $\mathrm{ZnO}$ 载体能够稳定 $\mathrm{Pt}$ 纳米颗粒表面的 $\mathrm{Pt}^{0}$ 物种. 上述催化剂在水相苯甲醇选择性氧化反应中, 在室温下即 可催化空气高选择性氧化苯甲醇到苯甲醛 (选择性> $99 \%$ ), 并表现出比 $\mathrm{Pt} / \mathrm{SiO}_{2}, \mathrm{Pt} / \mathrm{Al}_{2} \mathrm{O}_{3}, \mathrm{Pt} / \mathrm{TiO} \mathrm{O}_{2}, \mathrm{Pt} / \mathrm{Ca}(\mathrm{Mg}$ ) $-\mathrm{ZSM}-5$ 等催化 剂更为优异的催化活性. 这可归结于 $\mathrm{Pt}$ 和 $\mathrm{ZnO}$ 之间的协同作用. 该协同作用通过动力学实验和密度泛函理论计算 (DFT) 得到了证实. 氧分压实验表明, 在以空气为氧化剂时, $\mathrm{O}_{2}$ 的活化并不是限制 $\mathrm{Pt} / \mathrm{ZnO}$ 催化活性的关键因素, 而动力学同位素 效应实验则证实了苯甲醇的 $\mathrm{C}-\mathrm{H}$ 键活化是整个反应的决速步骤. 通过构建不同的理论模型, 分别计算了 $\mathrm{Pt} / \mathrm{ZnO}$ 界面处以 及纯 Pt 位点上苯甲醇选择性氧化的反应过程. 结果表明, 苯甲醇和氧气分子倾向于分别在 $\mathrm{ZnO}$ 和 Pt 上进行吸附, 随后由 吸附的氧气分子来活化苯甲醇中的 $\mathrm{C}-\mathrm{H}$ 键, 进而生成苯甲醛和水. 而当 $\mathrm{ZnO}$ 不参与苯甲醇的吸附活化时, 整个反应的活 化能会大大提高, 表明 $\mathrm{ZnO}$ 和 $\mathrm{Pt}$ 之间的协同作用对于整个反应至关重要. 此外, Pt/ZnO 表现出非常优异的稳定性, 循环使 用 4 次后, 催化剂结构以及催化活性没有显著变化.

进一步向 $\mathrm{Pt} / \mathrm{ZnO}$ 催化剂中引入少量 $\mathrm{Bi}$ 元素对 $\mathrm{Pt}$ 的电子结构进行修饰, 可以将 $\mathrm{Pt} / \mathrm{ZnO}$ 的催化活性提高 3 倍. 所制备 的 Pt/Bi-ZnO 复合物是目前报道的相同条件下催化苯甲醇选择性氧化反应转化频率 $\left(45.1 \mathrm{~h}^{-1}\right)$ 最高的催化剂.

关键词: 铂/氧化锌; 选择性氧化; 苯甲醇; C-H 活化; 水相; 室温

收稿日期: 2017-12-27. 接受日期: 2018-01-03. 出版日期: 2018-06-05.

*通讯联系人. 电话/传真: (0571)87952338; 电子信箱: xueshan199@163.com

\#通讯联系人. 电子信箱: hisabbit@yahoo.co.jp

\$通讯联系人. 电话/传真: (0571)87952338; 电子信箱: E-mail: jfan@zju.edu.cn

基金来源: 国家自然科学基金 (21703050, 21271153, 21373181); 中国博士后基金 (512200-X91701); 杭州电子科技大学青年教师 启动基金 (ZX150204307002/032).

本文的电子版全文由Elsevier出版社在ScienceDirect上出版(http://www.sciencedirect.com/science/journal/18722067). 